\title{
IMPLEMENTASI KONSEP KEADILAN RESTORATIF MELALUI PERAREM DESA ADAT RENON NOMOR 001/Par-DPR/VI/2017 TENTANG PERLINDUNGAN ANAK
}

\author{
Desak Putu Rini Larashati Subagia, Universitas Pendidikan Nasional Graduate \\ School Magister Hukum, e-mail: rinid86@yahoo.com \\ I Nyoman Budiana, Universitas Pendidikan Nasional, e-mail: \\ budiananyoman1961@gmail.com \\ Anak Agung Ayu Ngurah Tini Rusmini Gorda, Universitas Pendidikan \\ Nasional, e-mail: tinirusmini@undiknas.ac.id \\ doi: https://doi.org/10.24843/KS.2020.v08.i12.p12
}

\begin{abstract}
ABSTRAK
Tulisan ini bertujuan untuk mengetahui serta mengkaji penerapan serta pelaksanaan dari konsep keadilan restoratif yang tercantum dalam Perarem Desa Adat Renon Tentang Perlindungan Anak. Metode penelitian yang digunakan dalam tulisan ini yaitu menggunakan metode penelitian hukum empiris. Hasil penelitian ini menunjukkan bahwa dalam hal penerapan konsep keadilan restoratif melalui Perarem Desa Adat Renon Nomor 001/Par-DPR/VI/2017 tentang Perlindungan Anak khususnya dalam hal penyelesaian perkara anak yang cenderung ringan, di desa adat renon mengutamakan penyelesaian secara damai dan berdasarkan pemulihan keadilan guna memberikan perlindungan terhadap anak agar perkara tersebut tidak masuk ke ranah peradilan formal, serta menghindari anak dari labelisasi dalam masyarakat. Adanya keberlakuan perarem desa adat renon tentang perlindungan anak tersebut menjadi acuan serta memberikan penguatan dalam penyelenggaraan penyelesaian perkara anak berdasarkan konsep keadilan restoratif. Sehingga dalam hal implementasi atau pelaksanaan dari adanya perarem tersebut dapat dikatakan telah efektif diterapkan serta dilaksanakan di Desa Adat Renon.
\end{abstract}

Kata Kunci: Implementasi, Konsep Keadilan Restoratif, Perarem

\begin{abstract}
This paper aims to identify and examine the application and implementation of the concept of restorative justice as stated in the Perarem of the Traditional Village of Renon concerning Child Protection. The research method used in this paper is to use empirical legal research methods. The results of this study indicate that in terms of the application of the concept of restorative justice through Perarem Traditional Village Renon Number 001/Par-DPR/VI/2017 concerning Child Protection, especially in terms of resolving cases of children who tend to be mild, in traditional villages Renon prioritizes peaceful and recovery-based solutions in order to provide protection for children so that the case does not enter the realm of formal justice, and prevents children from being labeled in society. The implementation of the Renon traditional village regulations regarding child protection is a reference and provides reinforcement in the implementation of settlement of child cases based on the concept of restorative justice. So that in terms of implementation of the perarem, it can be said that it has been effectively implemented in the traditional village of Renon.
\end{abstract}

Keyword: Implementation, Restorative Justice Concept, Perarem 


\section{Pendahuluan}

\subsection{Latar Belakang Masalah}

Setelah dicabutnya ketentuan Undang-Undang Nomor 3 Tahun 1997 tentang Pengadilan Anak, kemudian di undangkannya Undang-Undang Nomor 11 Tahun 2012 tentang Sisten Peradilan Anak (selanjutnya disebut Undang-Undang SPPA), dalam hal penyelesaian perkara yang melibatkan anak dengan mengedepankan konsep keadilan restoratif yaitu penyelesaian tindak pidana dengan melibatkan pelaku, korban, keluarga dari korban, atau pelaku serta pihak terkait dengan permasalahan yang ada dengan menekankan pemulihan kembali dan bukan pembalasan, sebagaimana tercantum dalam ketentuan Pasal 1 angka 6 UndangUndang SPPA. Selain adanya konsep keadilan restoratif, dalam ketentuan UndangUndang SPPA juga menyebutkan mengenai diversi, sebagaimana tercantum dalam ketentuan Pasal 1 angka 7 menyebutkan bahwa diversi adalah pengalihan penyelesaian perkara anak dari proses peradilan pidana (penal) ke proses penyelesaian di luar peradilan pidana (non-penal). The Beijing Rules memberikan pengertian bahwa diversi adalah pemberian kewenangan kepada aparat penegak hukum untuk mengambil tindakan-tindakan kebijaksanaan dalam menangani ataupun menyelesaikan pelanggaran dan kejahatan yang melibatkan anak dengan tidak dilaksanakan secara formal atau dengan kata lain melepaskan dari proses penal atau diserahkan kepada orang tua, masyarakat dan bentuk-bentuk kegiatan pelayanan sosial lainnya ${ }^{1}$ Berkaitan dengan adanya konsep keadilan restoratif dan pelaksanaan diversi, dalam ketentuan UndangUndang SPPA menyebutkan pelaksanaan diversi dapat dilakukan apabila tindak pidana yang dilakukan oleh anak diancam dengan pidana penjara dibawah 7 (tujuh) tahun dan bukan bentuk pengulangan tindak pidana.

Mencermati adanya ketentuan mengenai adanya konsep keadilan restoratif dalam ketentuan Undang-Undang SPPA mengisyaratkan penyelenggaraan peradilan pidana anak khususnya terhadap penyelesaian perkara anak mendapat perhatian bahwa tidak semata-mata memberikan penghukuman terhadap anak namun memerhatikan pemulihan terhadap anak. Sejalan dengan hal tersebut, ketentuan undang-undang SPPA juga menyebutkan peran serta keterlibatan masyarakat melalui tokoh masyarakat dalam hal peran serta keterlibatannya dalam penyelesaian perkara anak tercantum dalam ketentuan BAB IX mengenai Peran Serta Masyarakat tepatnya dalam ketentuan Pasal 93 huruf d Undang-Undang SPPA menyebutkan bahwa masyarakat dapat berperan serta dalam perlindungan anak mulai dari pencegahan sampai dengan reintegrasi sosial anak dengan cara berpartisipasi dalam penyelesaian perkara anak melalui diversi dan pendekatan keadilan restoratif.

Desa adat melalui tokoh adat serta masyarakat yang mendiami wilayah desa adat memiliki kewajiban untuk bersama-sama melindungi anak. Konsep keadilan restoratif adalah suatu alternatif pendekatan restitutif terhadap pendekatan keadilan retributif dan keadilan rehabilitatif. ${ }^{2}$ Adanya konsep keadilan restoratif telah menggeser nilai filsafati penanganan anak dari penghukuman menuju rekonsiliasi, pembalasan terhadap pelaku menuju penyembuhan korban, pengasingan dan kekerasan menuju ke peransertaan dan kekerabatan masyarakat keseluruhan, destruktif yang negatif menuju ke perbaikan, pemberian maaf yang sarat dengan

1 Dian Ety Mayasari, "Perlindungan Hak Anak Kategori Juvenile Deliquency", Jurnal Ilmu Hukum Vol. 20 No. 3, Desember, 2018, hlm. 391.

2 Edi Setiadi, Kristian, Sistem Peradilan Pidana Terpadu dan Sistem Penegakan Hukum di Indonesia, (Jakarta, Kencana, 2017), 203. 
limpahan kasih. ${ }^{3}$ Melalui adanya pendekatan keadilan restoratif, penyelesaian kasus anak tidak hanya dengan melibatkan aparat penegak hukum yang umum dalam hal ini yaitu pihak kepolisian, tetapi dalam penyelesaian perkara anak baik desa adat melalui tokoh adat serta masyarakat memiliki peran serta terlibat dalam penyelesaian perkara tersebut. Sebagai salah satu desa adat di Bali yang menerapkan aturan mengenai penyelesaian perkara anak dengan menerapkan konsep keadilan restoratif yaitu di Desa Adat Renon Denpasar, melalui Perarem Desa Adat Renon Nomor 001/ParDPR/VI/2017 tentang Perlindungan Anak.

Melihat kenyataan inilah peran serta keterlibatan desa adat baik melalui tokoh adat serta lembaga adat yang ada di masing-masing daerah khususnya di Bali dalam kedudukannya sebagai aparat yang berwenang di desa adat ikut serta dilibatkan dalam mengambil keputusan terkait dengan penjatuhan sanksi atau tindakan lainnya yang bermanfaat bagi anak dan masyarakat dalam hal implementasi konsep keadilan restoratif. Menahan dan menjatuhkan pidana terhadap anak berhadapan dengan hukum khususnya pada tindak pidana ringan tidaklah menjadi jaminan persoalan kejahatan anak menjadi hilang. Akan tetapi justru membahayakan hak-hak dan kepentingan anak, karena penting untuk di ingat yaitu sekali anak masuk dalam sistem peradilan, maka pada saat itu anak akan selalu teringat dan bahkan dapat berpotensi menimbulkan dampak traumatis pada anak, bahkan lebih jauh lagi dapat menyebabkan perilaku kriminal yang lebih berbahaya bagi anak, keluarga dan masyarakat di masa mendatang.

Dalam beberapa artikel yakni artikel yang ditulis oleh Kuat Puji Prayitno yang berujudul "Restorative Justice Untuk Peradilan di Indonesia (Perspektif Yuridis Filosofis dalam Penegakan Hukum in Concerto)" 4 , Shinta Rukmi Budiastuti yang berjudul "Sanksi Pidana Anak Alternatif dalam Pembaharuan Hukum Pidana Indonesia" 5 dan artikel oleh Dian Ety Mayasari yang berjudul "Perlindungan Hak Anak Kategori Juvenile Delinquency Childern's Rights Protection in the Juvenile Deliquency Category"6 terdapat perbedaan pembahasan dengan tulisan ini. Tulisan ini lebih difokuskan dalam mengkaji dan menganalisis mengenai implementasi konsep keadilan restoratif melalui Perarem Desa Adat Renon Nomor 001/Par-DPR/VI/2017 tentang Perlindungan Anak khususnya dalam hal penyelesaian perkara anak yang cenderung ringan

\subsection{Rumusan Masalah}

Berdasarkan uraian latar belakang diatas, maka dapat dikemukakan pokok permasalahan yang akan dibahas dalam penelitian ini, yaitu: Bagaimanakah implementasi konsep keadilan restoratif dalam Perarem Desa Adat Renon Nomor 001/Par-DPR/VI/2017 tentang Perlindungan Anak?

Paulus Hadisuprapto, Pembaruan Sistem Peradilan Pidana Anak, (Yogyakarta, Aswaja Pressindo, 2016), 162.

4 Kuat Puji Prayitno, "Restorative Justice Untuk Peradilan di Indonesia (Perspektif Yuridis Filosofis dalam Penegakan Hukum in Concerto)", Dinamika Hukum Vol. 12, No. 3, (2012), hlm. 407-418.

5 Shinta Rukmi Budiastuti, "Sanksi Pidana Anak ALternatif dalam Pembaharuan Hukum Pidana Indonesia", Wacana Hukum Vol. IX, No. 1, (2010), hlm. 13-29.

6 Dian Ety Mayasari, "Perlindungan Hak Anak Kategori Juvenile Delinquency Childern's Rights Protection in the Juvenile Deliquency Category", Ilmu Hukum, Vol. 20, No. 3, (2018), hlm. 386400. 


\subsection{Tujuan Penulisan}

Adapun tujuan dilaksanakannya penelitian ini yaitu untuk mengetahui, mengkaji dan memahami tentang penerapan atau pelaksanaan dari konsep keadilan restoratif dalam perarem desa adat renon tentang perlindungan anak khususnya terkait dengan penyelesaian perkara yang melibatkan anak, baik anak sebagai korban maupun anak sebagai pelaku, atas adanya hal tersebut maka nantinya dapat dilihat apa sudah efektifkan implementasi konsep keadilan restoratif dalam ketentuan perarem tersebut.

\section{Metode Penelitian}

Jenis penelitian ini menggunakan jenis penelitian hukum empiris atau sering disebut dengan penelitian yuridis-sosiologis (sosio-legal research) merupakan penelitian hukum yang berupaya untuk melihat hukum dalam artian yang nyata atau dapat dikatakan penelitian hukum empiris merupakan penelitian yang melihat serta meneliti bagaimana bekerjanya hukum di masyarakat. ${ }^{7}$ Adapun sumber data yang digunakan dalam penelitian ini yaitu, sumber data primer dan sumber data sekunder. Sumber data primer yaitu data yang diperoleh dari sumber aslinya tanpa adanya perantara ${ }^{8}$, yang dalam hal ini penulis memperoleh data primer melalui wawancara dengan Bendesa Adat Renon. Sedangkan, sumber data sekunder merupakan sumber bahan hukum yang terdiri dari bahan hukum primer dan bahan hukum sekunder, yang mana bahan hukum ini diperoleh secara tidak langsung melalui media perantara, yang mana sumber bahan hukum merupakan hasil penelitian yang sudah teruji secara ilmiah. ${ }^{9}$ Teknik pengumpulan data yang digunakan dalam penelitian ini yaitu dalam pengumpulan sumber data primer dilakukan dengan wawancara dan pengumpulan sumber data sekunder dengan studi dokumen. Adapun teknik analisis data yang digunakan dalam penelitian ini yaitu teknik analisis model Miles dan Huberman ${ }^{10}$, yaitu dalam menganalisis data yang diperoleh dengan melaksanakan 4 (empat) langkah yaitu: pengumpulan data (data collection), reduksi data (data reduction), penyajian data (data display), dan penarikan kesimpulan (conclusion drawing/verification).

\section{Hasil dan Pembahasan}

3.1 Implementasi Konsep Keadilan Restoratif Melalui Perarem Desa Adat Renon Nomor 001/Par-DPR/VI/2017 tentang Perlindungan Anak

Pembicaraan tentang anak dan perlindungan anak tidak pernah berhenti sepanjang perjalanan kehidupan. Anak merupakan generasi penerus bangsa yang dipersiapkan sebagai subjek pelaksana pembangunan berkelanjutan dimasa mendatang yang perlu diberi pembinaan serta perlindungan baik dari segi fisik maupun mental. Sejalan dengan hal tersebut, dalam ketentuan Pasal 28 UndangUndang Dasar Negara Republik Indonesia Tahun 1945 (selanjutnya disebut UUD NRI Tahun 1945) menyebutkan bahwa setiap anak berhak atas kelangsungan hidup, tumbuh dan berkembang serta berhak atas perlindungan dari kekerasan dan

7 Elisabeth Nurhaini Butarbutar, Metode Penelitian Hukum Langkah-Langkah Untuk Menemukan Kebenaran dalam Ilmu Hukum, (Bandung, PT. Refika Aditama, 2018), 95.

8 Amirudin, Zainal Asikin, Pengantar Metode Penelitian Hukum, (Jakarta, PT. RajaGrafindo Persada, 2016), 31.

9 Ibid.

10 Sugioyono, Metode Penelitian Kualitatif, (Bandung, Alfabeta, 2018), 132. 
diskriminasi, hal ini menjadi dasar bagaimana pentingnya memberikan perlindungan terhadap anak.

Sebagai salah satu bentuk perlindungan anak yaitu terkait dengan penyelesaian perkara yang melibatkan anak, yang awalnya dengan pemberian sanksi dalam bentuk pembalasan (hukuman), namun sejak diundangkanya Undang-Undang SPPA terhadap anak yang berhadapan dengan hukum dalam hal penyelesaian perkaranya menekankan proses diversi dan mengedepankan keadilan pemulihan atau dengan keadilan restoratif (restorative justice). dalam ketentuan Pasal 5 Ayat (1) menyebutkan bahwa dalam sistem peradilan pidana anak diwajibkan untuk mengutamakan pendekatan keadilan restoratif, kemudian dijelaskan dalam ketentuan Ayat (2) bahwa sistem peradilan pidana anak sebagaimana disebutkan dalam ayat (1) meliputi :

1. Penyidikan dan penuntutan pidana anak yang dilaksanakan sesuai dengan ketentuan peraturan perundang-undangan, kecuali ditentukan lain oleh Undang-Undang ini;

2. Persidangan anak yang dilakukan oleh pengadilan di lingkungan peradilan umum; dan

3. Pembinaan, pembimbingan, pengawasan, dan/atau pendampingan selama proses pelaksanaan pidana atau tindakan dan setelah menjalani pidana atau tindakan.

Sebagaimana tercantum dalam ketentuan Pasal 1 Ayat (3) Undang-Undang Dasar Negara Republik Indonesia Tahun 1945 yang menyebutkan bahwa Indonesia adalah Negara hukum, dapat diartikan bahwa Negara Indonesia memiliki kewajiban untuk melindungi warganya sejak dalam kandungan hingga meninggal. Berkaitan dengan perlindungan anak, Indonesia telah meratifikasi Konvensi Hak-Hak Anak yang tercantum dalam Keputusan Presiden Republik Indonesia Nomor 36 Tahun 1990 tentang Pengesahan Convention on the Rights of The Child 1989 atau Konvensi Hak-Hak Anak, yang mana dengan meratifikasi konvensi tersebut maka setiap produk hukum yang berkaitan dengan anak diharuskan untuk selalu berpedoman dengan Konvensi Hak-Hak Anak tersebut, khsusunya disebutkan dalam ketentuan Pasal 37 huruf b, yang menyebutkan: "No child shall be deprived of his or her liberty unlawfully or orbitratily. The arrest, detention or imprisonment of a child shall be in conformity with the law and be used onley as aeasure of last resort and for the shortest appropriate period of time."11

Selain adanya konvensi yang disebutkan sebelumnya, terdapat pula konvensi yang dianggap penting terkait dengan perlindungan terhadap hak-hak anak yang berhadapan dengan hukum, yaitu tercantum dalan The Unites Nation Standard Minimum Rules for The Administrations of Juveniles Justice atau yang dikenal dengan The Beijing Rules yang pada prinsipnya menyebutkan bahwa dalam hal sistem peradilan bagi anak mengutamakan adanya kesejahteraan anak, sehingga terhadap aparat penegak hukum baik polisi, penuntut umum serta hakim dalam menangani perkara anak diberi kuasa untuk memutus perkara menurut kebijaksanaan mereka, tanpa menggunakan pemeriksaan awal dan formal, serta berhak untuk mengakhiri proses peradilan pada setiap saat, dan penempatan anak pada suatu lembaga merupakan

11 Juwita Arsawati, "Kebijakan Formulasi Pidana Pengawasan Anak yang Berkonflik dengan Hukum, Disertasi, Program Doktor Ilmu Hukum, Universita Udayana, Denpasar, (2016), hlm. 3 . 
pilihan terakhir dengan jangka waktu yang sesingkat mungkin. Begitu pula dalam hal pembebasan bersyarat sejauh mungkin digunakan oleh pihak berwenang yang layak. ${ }^{12}$

Sebagaimana tercantum dalam ketentuan Pasal 1 angka 2 Undang-Undang Nomor 35 Tahun 2014 tentang Perubahan Atas Undang-Undang Nomor 23 Tahun 2002 tentang Perlindungan Anak (selanjutnya disebut Undang-Undang Perlindungan Anak) yang menyebutkan bahwa perlindungan anak adalah segala kegiatan untuk menjamin dan melindungi anak dan hak-haknya agar nantinya dapat hidup, tumbuh, berkembang dan berpartisipasi secara optimal sesuai dengan harkat dan martabat kemanusiaan, serta mendapat perlindungan dari kekerasan dan diskriminasi.

Perlindungan hukum merupakan suatu hal yang sangat penting untuk dikaji, karena menyangkut pada perlindungan yang diberikan kepada masyarakat, yaitu masyarakat yang berada pada posisi yang lemah, baik secara ekonomis maupun lemah ditinjau dari aspek yuridis. Berkaitan dengan penelitian ini maka pengertian perlindungan hukum yang dimaksudkan adalah perlindungan hukum terhadap hak asasi anak, serta kepentingan yang berhubungan dengan kepentingan terbaik bagi anak yang telah diatur dalam undang-undang

Anak sebagai generasi penerus bangsa berhak mendapatkan perlindungan. Perlindungan terhadap anak dapat dibedakan menjadi 2 (dua), yaitu13 :

1. Perlindungan anak yang bersifat yuridis, dalam hal ini meliputi perlindungan dalam bidang hukum publik dan dalam bidang hukum keperdataan; dan

2. Perlindungan anak yang bersifat non-yuridis, dalam hal ini meliputi bidang sosial, bidang kesehatan dan bidang pendidikan.

Adanya keberlakuan undang-undang tentang perlindungan anak khususnya di Indonesia sebagaimana diketahui telah mengalami suatu kemajuan. Hal ini dalam arti bahwa, dalam keberlakuan undang-undang tentang perlindungan anak sekarang ini menunjukkan bahwa pemerintah telah memberikan perhatian terkait dengan pertumbuhan dan perkembangan anak sebagai generasi penerus bangsa, khususnya terhadap anak yang berhadapan dengan hukum. Terkait dengan hal tersebut maka dalam hal upaya perlindungan anak harus dimulai sedini mungkin agar kelak dimasa depan anak dapat berpartisipasi secara optimal guna sebagai penerus bangsa yang berkaitan dengan pembangunan bangsa dan Negara di masa mendatang.

Berkaitan dengan hal tersebut, dalam hal perlindungan anak tidak hanya dilakukan berdasarkan keberlakuan hukum positif namun juga berdasarkan aturan atau kaidah-kaidah hukum yang berlaku dalam kehidupan masyarakat, khususnya masyarakat adat di Bali. Sebagai salah satu contohnya, yaitu adanya pararem tentang perlindungan anak di Desa Adat Renon Denpasar. Berdasarkan data yang penulis peroleh dari hasil wawancara dengan Bapak I Wayan Suarta selaku Bendesa Adat renon menyebutkan bahwa dalam penyelesaian kasus anak berdasarkan ketentuan perarem desa adat renon nomor 001/Par-DPR/VI/2017 tentang Perlindungan Anak guna menghindarkan anak dari penyelesaian perkara secara formal. Adapun beberapa hal yang diatur dalam perarem ini yaitu: perlindungan serta pengayoman terhadap anak, menghilangkan diskriminasi khususnya terhadap anak yang berhadapan dengan hukum, memberikan penyadaran terhadap anak, serta penentuan penjatuhan sanksi

12 Arsawati, Ni Nyoman Juwita. Menyoal sanksi pidana anak yang berkonflik dengan hukum. Udayana University Press, 2017. hlm. 6.

13 Maidin Gultom, Perlindungan Hukum Terhadap Anak dalam Sistem Peradilan Pidana Anak di Indonesia, (Bandung, Refika Aditama, 2010), 34. 
adat bagi anak yang kedapatan melakukan pelanggaran yang disebutkan sesuai dalam ketentuan perarem ini.

Adanya keberlakuan perarem ini juga atas dasar maraknya perkara anak khususnya yang terjadi di Desa Adat Renon Denpasar, lalu masih dijumpai keinginan di salah satu pihak dalam hal penyelesaian kasus tersebut dengan pemidanaan. Jenisjenis kasus yang pernah terjadi yaitu keterlibatan anak dengan geng motor, trek-trekan dan kekerasan antar anak. Kasus yang paling di sorot dan berulang kali terjadi di Desa Adat Renon yaitu adanya keterlibatan anak dalam trek-trekan, yang mana kasus tersebut terjadi pertama kali pada tahun 2012, yang pada saat kejadian anak-anak tersebut diamankan oleh pihak pecalang Desa Adat Renon. Berkaitan dengan adanya beberapa perkara yang melibatkan anak tersebut, dalam hal penyelesaiannya, Bendesa Adat Renon menambahkan sekalipun ketika kasus itu sudah ada dan terjadi tetapi dalam hal perarem belum tertulis, namun dalam hal penyelesaiannya juga diupayakan damai, karena di setiap desa adat khususnya di Desa Adat Renon-pun memiliki aturan tidak tertulis yang berlaku dalam kehidupan masyarakat. ${ }^{14}$

Sebagaimana tercantum dalam ketentuan Pawos 7 Perarem Desa Adat Renon Nomor 001/Par-DPR/VI/ 2017 tentang Perlindungan Anak menyebutkan bahwa :

1. Terhadap anak yang berhadapan dengan hukum mendapat perlindungan;

2. Anak yang disebutkan sesuai dengan perarem ini adalah anak yang berusia dibawah 18 (delapan) belas tahun, mengacu pada ketentuan UndangUndang SPPA);

3. Apabila terjadi suatu perkara yang melibatkan anak, dalam hal penyelesaiannya diselesaikan secara kekeluargaan atau terhadap tindakan tersebut harus diselesaikan sesuai dengan hukum adat berdasarkan prinsip musyawarah (paras paros sarpana ya), gotong royong (salunglung sabayan taka), asah, asih dan asuh ataupun dengan kekeluargaan.

4. Adapun wicara atau perkara adat yang diatur dan dapat diselesaikan disini yaitu wicara atau tindak pidana ringan (mengacu Undang-Undang SPPA), antara lain :
a. wicara pewiwahan;
b. wicara indik mamaling;
c. wicara perkelahian;
d. wicara marikosa;
e. wicara sane siosan (seperti: trek-trekan, narkoba, miras, dll).

Selanjutnya, tercantum mengenai reintegrasi anak berhadapan dengan hukum di masyarakat desa adat renon, dalam hal ini tercantum dalam ketentuan Pawos 11, yang menyebutkan bahwa desa adat berkewajiban untuk melakukan pembinaan terhadap anak yang berhadapan dengan hukum berbasis kearifan lokal dengan mengedepankan budi pekerti dan keagamaan, baik terhadap anak yang berkonflik dengan hukum maupun anak yang telah menjalani masa hukuman. Selain hal tersebut, dalam ketentuan pawos ini disebutkan kewajiban desa adat renon untuk melakukan pemulihan perasaan masyarakat akibat tindakan yang dilakukan oleh anak berhadapan dengan hukum guna meminimalisir stigma atau labelisasi.

Masyarakat dalam kehidupannya memerlukan suatu aturan untuk menciptakan hubungan dan suasana yang harmonis. Adapun aturan tersebut merupakan hukum, baik berupa hukum tertulis maupun hukum yang tidak tertulis. Pembuatan atau penyusunan suatu produk hukum yang hidup di dalam masyarakat memiliki sifat

14 Wawancara dengan Bendesa Adat Renon, tanggal 20 Oktober 2020. 
dinamis yang berarti mengikuti perkembangan dari masyarakat, yang mana hukum dibuat dan nantinya akan berlaku di masyarakat hendaknya mampu berlaku secara efektif. ${ }^{15}$ Jika membicarakan masalah efektif atau berfungsi tidaknya suatu hukum dalam arti undang-undang maupun produk hukum lainnya, maka pada umumnya pikiran diarahkan pada kenyataan apakah hukum tersebut benar-benar berlaku atau tidak dalam kehidupan masyarakat.

Sejalan dengan hal tersebut, berkaitan implementasi konsep keadilan restoratif dalam perarem desa adat renon tersebut dikaitkan dengan teori efektivitas hukum menurut Soerjono Soekanto, yang menyatakan bahwa terdapat beberapa faktor yang menjadi indikator agar suatu peraturan atau kaidah hukum benar-benar berfungsi sebagaimana mestinya, yaitu:

a. Faktor Hukumnya Sendiri.

Hukum berfungsi untuk keadilan, kepastian dan kemanfaatan. Hukum tidak hanya dilihat dari sudut hukum tertulis saja, namun masih banyak aturan yang hidup dalam masyarakat yang mampu mengatur kehidupan masyarakat. Jika hukum tujuannya hanya sekedar keadilan, maka kesulitannya adalah keadilan bersifat subjektif sangat tergantung pada nilai-nilai intrinsik subjektif dari masing-masing orang. ${ }^{16}$ Berkaitan dengan faktor hukumnya sendiri dalam hal ini yaitu adanya ketentuan Perarem Desa Adat Renon Nomor 001/ParDPR/VI/2017 tentang Perlindungan Anak sebagai bentuk aturan yang hidup dalam masyarakat, yang dapat mengatur kehidupan masyarakatnya dalam hal ini masyarakat di Desa Adat Renon.

b. Faktor Penegak Hukum.

Mengenai berfungsinya hukum, mentalitas atau kepribadian penegak hukum memliki peranan penting dalam hal membentuk maupun menerapkan suatu aturan hukum. Jika peraturan sudah baik namun kualitas penegak hukum kurang baik maka hal tersebut menjadi suatu permasalahan. Melihat faktor ini, terkait dengan implementasi konsep keadilan restoratif dalam perarem tentang perlindungan anak yaitu dalam peran tokoh masyarakat adat khususnya di Desa Adat Renon tersebut. Dalam hal penerapan aturan dalam hal ini perarem tentang perlindungan anak, melalui tokoh adat yang dalam hal ini disebut sebagai prajuru desa adat renon. Penyelesaian perkara yang dilakukan oleh prajuru desa adat renon mengacu pada ketentuan perarem perlindungan anak tersebut, yang mana penyelesaian perkara anak dengan berasaskan kedamaian serta dengan pemulihan keadilan.

c. Faktor Sarana dan Fasilitas.

Sarana serta fasilitas merupakan salah satu faktor penting dalam menunjang dalam penegakan hukum. Tanpa adanya sarana serta fasilitas tersebut maka penegak hukum tidak akan mungkin menyerasikan peranan yang seharusnya dengan peranan yang aktual. Terkait dengan hal tersebut, sarana dan fasilitas dalam implementasi konsep keadilan restoratif melalui perarem tentang perlindungan anak tersebut telah mendukung. Pelaksanaan keadilan restoratif melalui adanya perarem desa adat renon tentang perlindungan anak diperkuat dengan adanya ketentuan Undang-Undang SPPA. Serta, khususnya di provinsi Bali telah memiliki Peraturan Daerah

15 Muhammad Syukri Albani Nasution, (et.al), Hukum dalam Pendekatan Filsafat, (Jakarta, Kencana, 2016), 296.

16 Ibid, hlm. 297. 
Provinsi Bali Nomor 6 Tahun 2014 tentang Perlindungan Anak, serta Peraturan Daerah Provinsi Bali Nomor 4 Tahun 2019 tentang Desa Adat di Bali, yang mana dalam ketentuan peraturan daerah tersebut mewajibkan desa adat untuk melindungi, megatur serta bertanggungjawab terhadap masyarakatnya, khususnya terhadap anak. Selain hal tersebut, terkait dengan fasilitas, berdasarkan hal wawancara penulis dengan bedesa adat renon, guna memberikan pembinaan terhadap anak yang berhadapan dengan hukum maupun untuk menekan terjadinya perkara yang melibatkan anak, Desa Adat Renon membentuk perkumpulan seperti sekeha gong, pesraman, sekeha tari, serta kegiatan lain yang mengarah pada pembinaan dan pembimbingan terhadap anak.

d. Faktor Masyarakat.

Masyarakat merupakan faktor yang mempengaruhi dalam efektivitas hukum. Jika masyarakat tidak sadar akan adanya hukum maka ke-efektivan hukum tidak akan terlaksana. Kesadaran hukum merupakan konsepsi abstrak yang ada dalam diri masing-masing individu manusia tentang keserasian antara ketertiban dan ketentraman yang dikehendaki atau sepantasnya. Dikaitkan dengan kesadaran masyarakat, khususnya masyarakat adat di Desa Adat Renon, bias dikatakan memiliki kesadaran terhadap anak. Bendesa Adat menyebutkan bahwa, kegiatan rutin yang dilaksanakan yaitu dengan memberikan sosialisasi kepada para orang tua khususnya kepada ibu-ibu PKK serta sekeha truna truni guna memberikan penyadaran pentingnya perlindungan anak, karena masalah tentang anak merupakan urgensi terhadap kita sebagai penggiat perlindungan anak.

e. Faktor Kebudayaan.

Menurut Soerjono Soekanto, kebudayaan mempunyai fungsi yang sanagat besar bagi manusia dan masyarakat, yaitu mengatur agar manusia dapat mengerti bagaimana seharusnya bertindak, berbuat dan menentukan sikapnya dikala berhubungan dengan orang lain. Dapat dikatakan bahwa kebudayaan merupakan suatu garis pokok tentang perikelakuan yang menetapkan peraturan mengenai yang harus dilakukan dan mengenai hal-hal yang dilarang. ${ }^{17}$ Terkait dengan faktor kebudayaan tersebut, dalam berperikelakuan, dapat dicermati bahwa masyarakat yang mendiami wilayah Desa Adat Renon tunduk dan patuh terhadap adanya ketentuan perarem tentang perlindungan anak tersebut. Baik terhadap masyarakat adat asli (karma wed), masyarakat pendatang beragama hindu (karma tamiu), dan pendatang (tamiu).

Sebagaimana telah diuraikan diatas, kelima faktor dalam teori efektivitas hukum yang dikemukakan oleh Soerjono Soekanto tersebut saling berkaitan satu dengan yang lainnya, karena faktor-faktor tersebut menjadi hal pokok dalam hal penegakan hukum serta sebagai tolok ukur efektif atau tidaknya penegakan hukum.

\section{Kesimpulan}

Implementasi konsep keadilan restoratif yang termuat dalam ketentuan Perarem Desa Adat Renon Nomor 001/Par-DPR/VI/2017 tentang Perlindungan Anak dapat dikatakan efektif dalam keberlakuannya menegakkan hukum. Khususnya, dalam hal

\footnotetext{
${ }^{17} \mathrm{Ibid}, \mathrm{hlm} .301$.
} 
penyelesain perkara yang melibatkan anak, diselesaikan dengan mengedapankan keadilan restoratif atau keadilan pemulihan. Selain hal tersebut dapat dicermati bahwa sebagai fokus terhadap masyarakat Bali khususnya terhadap masyarakat Desa Adat Renon yang telah memberikan satu konsep pemikiran mengenai respon dari UndangUndang SPPA untuk menyelesaikan perkara anak dengan penerapan konsep keadilan restoratif dalam perarem tentang perlindungan anak. Terkait keefektivan dari implementasi konsep keadilan restoratif dalam perarem desa adat renon tentang perlindungan anak juga dapat dicermati dalam adanya lima faktor yang menjadi indikator efektif tidaknya suatu aturan yang berlaku dalam masyarakat khususnya di Desa Adat Renon. Dengan adanya perarem ini juga memberikan ruang bagi kesatuan hukum adat dalam hal ini desa adat di Bali melalui tokoh adatnya untuk bisa terlibat dalam penyelesain perkara anak sesuai dengan sistem peradilan pidana anak.

\section{DAFTAR PUSTAKA \\ Buku}

Amirudin, Asikin, Zainal, Pengantar Metode Penelitian Hukum, (Jakarta, PT. RajaGrafindo Persada, 2016).

Butarbutar, Elisabeth Nurhaini, Metode Penelitian Hukum Langkah-Langkah Untuk Menemukan Kebenaran dalam Ilmu Hukum, (Bandung, PT. Refika Aditama, 2018).

Gultom, Maidin, Perlindungan Hukum Terhadap Anak dalam Sistem Peradilan Pidana Anak di Indonesia, (Bandung, Refika Aditama, 2010).

Hadisuprapto, Paulus, Pembaruan Sistem Peradilan Pidana Anak, (Yogyakarta, Aswaja Pressindo, 2016).

Nasution, Muhammad Syukri Albani (et.al), Hukum dalam Pendekatan Filsafat, (Jakarta, Kencana, 2016).

Setiadi, Edi, Kristian, Sistem Peradilan Pidana Terpadu dan Sistem Penegakan Hukum di Indonesia, (Jakarta, Kencana, 2017).

Sugioyono, Metode Penelitian Kualitatif, (Bandung, Alfabeta, 2018).

\section{Jurnal Ilmiah}

Astrid Ayu Pravitria, "Anak yang Berkonflik dengan Hukum yang Melakukan Pemerkosaan Terhadap Anak", Media Iuris, Vol. 1 No. 3, Oktober (2018).

Chairul Bariah, "Perluasan Pertanggungjawaban Terhadap Tindak Pidana yang Dilakukan oleh Anak", Syiah Kuala Law Journal, Vol. 1, No. 3, Desember (2017).

Destri Tsurayya Istiqamah, "Analisis Nilai Keadilan Restoratif Pada Penerapan Hukum Adat di Indonesia", Jurnal VeJ, Vol. 4, No.1, Juni (2018).

Dian Ety Mayasari, "Perlindungan Hak Anak Kategori Juvenile Deliquency", Jurnal Ilmu Hukum, Vol. 3 No. 20, (2018).

Dony Pribadi, "Perlindungan Terhadap Anak Berhadapan dengan Hukum", Jurnal Hukum Volkgeist, Vol. 3, No.1, Desember (2018).

I Ketut Sudantra, dkk, "Sistem Peradilan Adat dalam Kesatuan-Kesatuan Masyarakat Hukum Adat Desa Pakraman di Bali", Jurnal Kajian Bali, Vol. 7, No. 1, April (2017).

Kuat Puji Prayitno, "Restorative Justice Untuk Peradilan di Indonesia (Perspektif Yuridis Filosofis dalam Penegakan Hukum in Concerto)", Jurnal Dinamika Hukum, Vol/ 12 No. 3, Desember (2012).

Nadia Oktaviani Zulfa, dkk, “Implementasi Diversi Sebagai Wujud Perlindungan Hak Anak", Jurnal Ilmu Hukum - GEMA, XXVII/50/Pebruari-Juli, FH UNS Surakarta, (2015). 
Ni Nyoman Juwita Arsawati, AAA. Ngr. Tini Rusmini Gorda, "Legal Reform dalam Penjatuhan Sanksi Terhadap Anak Pelaku Kejahatan", Jurnal Analisis Hukum, Vol. 1, No. 1, April (2018).

Philia Anindita Ginting, Meilanny Budiarti Santoso, "Perubahan Perilaku Anak Berhadapan dengan Hukum (ABH)", Social Work Jurnal, Vol. 9, No. 1.

Rendy H. Pratama, dkk, "Perlindungan Hukum Terhadap Anak yang Berhadapan dengan Hukum", Prosiding KS: Riset\&PKM, Vol. 2, No.1.

Shinta Rukmi Budiastuti, "Sanksi Pidana Alternatif dalam Pembaharuan Hukum Pidana Indonesia", Jurnal Wacana Hukum, Vol. IX, No. 1, April (2010).

Meinarda Simanjorang, dkk, “Upaya Hukum dalam Melindungi Anak Sebagai Kurir Narkotika Berdasarkan Undang-Undang No. 11 Tahun 2012 tentang Sistem Peradilan Pidana Anak", Jurnal Tectum LPPM Univ. Asahan, Vol. 1 No. 1, November (2019).

Yusuf Istanto, "Pelaksanaan Restorative Justice Terhadap Anak Pelaku Tindak Pidana Lalu Lintas (Studi Pelaksanaan Restorative Justice di Polres Kudus)", Jurnal Panorama Hukum, Vol. 2, No. 1, Juni (2017).

\section{Perundang-undangan}

Undang-Undang Dasar Negara Republik Indonesia Tahun 1945

Undang-Undang Nomor 11 Tahun 2012 tentang Sistem Peradilan Pidana Anak

Undang-Undang Nomor 35 Tahun 2014 tentang Perubahan Atas Undang-Undang Nomor 23 Tahun 2002 tentang Perlindungan Anak

Peraturan Daerah Provinsi Bali Nomor 4 Tahun 2019 tentang Desa Adat di Bali

Peraturan Daerah Provinsi Bali Nomor 6 Tahun 2014 tentang Perlindungan Anak 